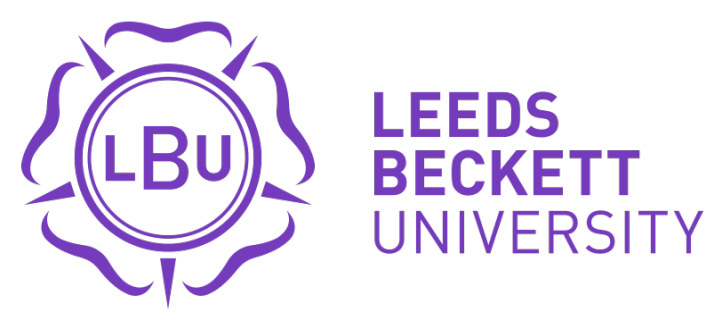

Citation:

Carless, D and Douglas, K (2009) Opening doors: Poetic representation of the sport experiences of men with severe mental health difficulties. Qualitative Inquiry, 15 (10). 1547 - 1551. ISSN 1077-8004 DOI: https://doi.org/10.1177/1077800409332081

Link to Leeds Beckett Repository record:

https://eprints.leedsbeckett.ac.uk/id/eprint/921/

Document Version:

Article (Accepted Version)

The aim of the Leeds Beckett Repository is to provide open access to our research, as required by funder policies and permitted by publishers and copyright law.

The Leeds Beckett repository holds a wide range of publications, each of which has been checked for copyright and the relevant embargo period has been applied by the Research Services team.

We operate on a standard take-down policy. If you are the author or publisher of an output and you would like it removed from the repository, please contact us and we will investigate on a case-by-case basis.

Each thesis in the repository has been cleared where necessary by the author for third party copyright. If you would like a thesis to be removed from the repository or believe there is an issue with copyright, please contact us on openaccess@leedsbeckett.ac.uk and we will investigate on a case-by-case basis. 
Running head: OPENING DOORS

\section{Opening Doors:}

Poetic Representation of the Sport Experiences of Men with Severe Mental Health Difficulties

David Carless, Leeds Metropolitan University

Kitrina Douglas, University of Bristol

Published as: Carless, D. \& Douglas, K. (2009). Opening doors: Poetic representation of the sport experiences of men with severe mental health difficulties. Qualitative Inquiry, 15(10), 15471551.

Correspondence:

David Carless

Leeds Metropolitan University

Carnegie Research Institute

Headingley Campus

Leeds, LS6 3QS, UK

Phone: +44 7879647227

Fax : +44 1132837575

Email: d.carless@leedsmet.ac.uk 


\begin{abstract}
We present here a series of poetic representations which stem from our research into the sport and exercise experiences of men with severe mental health difficulties. Relying exclusively on scientific or realist tales risks omitting or misrepresenting participants’ sometimes “messy” stories. By allowing space for these stories - which may not be considered "good stories" in terms of traditional narrative criteria of content, form, coherence, or plot - poetic approaches can contribute to a richer and more complex understanding of others' lives. The first poem was written in response to our experiences of doing qualitative research in the context of a rehabilitation day centre for people with severe mental health difficulties. We created the subsequent poems, using only the participants’ own words, as a way to further explore and represent their experiences of, and responses to, a golf activity group which was offered within the context the day centre.
\end{abstract}

Keywords: mental health, narrative, poetry, recovery, representation, sport 
The Pepper Pot

The pepper pot sat on the table

Minding it's business and still

Standing upright in the centre

Of the café for those who are ill

Does he mind if I use a recorder?

Does he mind if I listen and care?

I just wanted to ask a few questions

Just wanted to see and be there

The pepper pot sprang into action

Two taps to the left then the right

A quick pirouette and then shaken

Depositing dust in the air

The pepper told the story

But no words were spoken that day

Held tight in a fist by one in a mist

Like pepper, lost in the air 
Doors

I was persuaded to go

can’t remember who

Wasn't going to go

But when I found it wasn't permanent

felt I'd lost nothing really

It was good time out

not a hectic sport

out and about,

Out

in the country

The city gets hectic

I like a breather

to myself

A sport of relaxation

gets your mind

on another track

It takes your mind off

temporarily

while it's going on

I do like doing things

outside of mental health

When it's something outside 
you feel

free

That's all

No disrespect to the people

I wouldn't say it to their faces

But I just like to feel normal

like having the door opened

instead of always shut.

Peter's Stuff

I was interested ‘cause I’d played before

(a long time ago)

It was only just a one-off

I went mad, just went out

spent some money on clubs

got into it I suppose

I thought I'd give it a go

got me interested again

If I can use those clubs, my gloves, my hat

'Cause it’s my own personal equipment, say

I feel it's important I should use it 
and get fulfillment out of it.

$O-K$

I'll tell you what I think of the golf

I can say it in one word:

$\mathrm{O}-\mathrm{K}$

alright, act $-\mathrm{u}-$ all $-\mathrm{y}$

and I haven’t insulted staff

we haven't been insulting

and that is pro - gress

you should be pleased with that

I like it light hearted

can't stand in - ten - sit - y

can’t handle people mocking

mock - ing - me

I’m not happy about my appearance

worry about it

But like to think at sport

I've got $a b-i l-i t-y$ 
Getting It Back Together Again

Awhile back

attempted suicide

physical injuries

I was heavily medicated

lot of hassle going outdoors

I was paralyzed

had to wear a corset

\author{
I was feeling $\mathrm{OK}$ in May \\ feeling ill in March \\ Oh, hassles (situations) \\ feel panicky (get a panic attack) \\ I need a break from indoors \\ get out, do something \\ an activity, not watching TV
}

I'm surprised I enjoyed it this much

Not getting as many

side-effects

symptoms 
whatever.

It’s enjoyable.

Gets rid of some stress.

I can cope with situations.

Part of the package.

Know what I mean?

That went up nicely,

not all that far but really straight.

Direction just right.

Yeah, good result

wind up follow-through

A proper swing, the last two shots

followed through

improved (the swing),

the proper thing

I did a proper swing

It's a bit of a relief

to know

I'm getting it back together again. 
Join the Club

No, no, I don’t think so,

I think I'd need more practice

on an ordinary course

like the pitch and putt

get familiar, there’s a step

No, no, I'd feel out of place

don't know anybody there

the operation of the club

I don't know how it works

No, no, I don’t know

if they let people play up there

they only allow certain people

to go up there to play

That's what I want to do

actually

if I can

I'd love to do that. 


\section{Biographies}

David Carless, Ph.D., is currently a Senior Research Fellow at Leeds Metropolitan University, UK. His research focuses on using a variety of narrative and arts-based approaches to explore identity, mental health and psychological well-being in and through physical activity and sport.

Kitrina Douglas, Ph.D., played golf on the Ladies European Tour for twelve years and has worked in broadcasting and the media. Since 1996 she has been conducting narrative and artsbased research in the areas of sport, exercise, and health and is currently an Honorary Visiting Fellow at the University of Bristol, UK. 